\title{
ПРО СТАН СУСПІЛЬНОЇ СВІДОМОСТІ ТА ЗАХОДИ З ЙОГО ПОЛІПШЕННЯ В УМОВАХ ПАНДЕМІї COVID-19
}

\section{Науково-аналітична доповідь}

https://doi.org/10.37472/2707-305X-2020-2-2-14-2

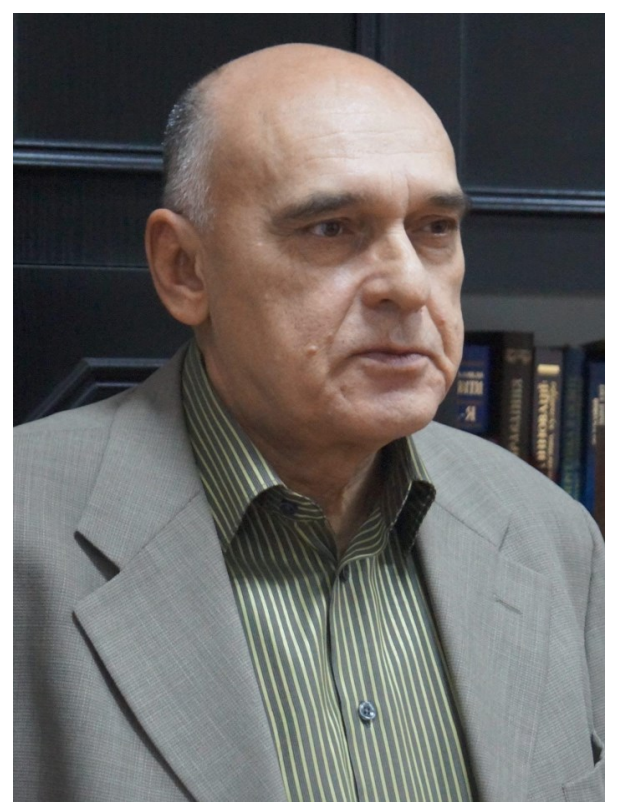

\section{СЛЮСАРЕВСЬКИЙ}

\section{Микола Миколайович}

кандидат психологічних наук, член-кореспондент НАПН України, директор Інституту соціальної та політичної психології Начіональної академії педагогічних наук України, м. Київ, Україна

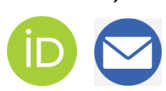

Анотація. Проаналізовано результати попередніх досліджень стану суспільної свідомості в Україні в умовах пандемії COVID-19 ma виокремлено провідні тенденції і суперечності суспільної реакції на пандемічні загрози. Зокрема, показано, що інтенсивність стресової реакції на ризик захворіти серед громадян України виявилася досить помірною. Основним джерелом стресу $\epsilon$ не хвороба як така, а суцільна невизначеність і невпевненість у власному економічному майбутньому. Розглянуто провокативні чинники, які можуть посилювати суперечності в масовій свідомості та підвищувати вірогідність саботажу і спротиву громадян упровадженню карантинних обмежувальних заходів у зв'язку із новими хвилями пандемії. Виокремлено актуальні завдання у срері забезпечення гармонійних суспільних відносин і підтримання психоемоційного стану населення в межах норми. Перше - домогтися масового дисциплінованого дотримання громадянами мінімуму необхідних заходів безпеки та дистаниіювання в умовах фрактичної відміни зовнішніх обмежувальних заходів, що знизить загрозу розвитку нових епідеміологічних спалахів. Друге - нейтралізувати або істотно послабити тендениії до зростання протестних настроїв, соціального невдоволення і відиентрових тенденцій, що дасть змогу зберегти керованість ситуачією.

Ключові слова: пандемія; суспільна свідомість; ризики; обмежувальні заходи; стрес.

Вчені Національної академії педагогічних наук України разом із фахівцями інших наукових установ і закладів вищої освіти систематично здійснюють дослідження психоемоційних станів населення, спричинених пандемією COVID-19, та їх соціальнопсихологічних наслідків (обмін попередніми даними досліджень серед академічних психологів і соціологів відбувся, зокрема, 15 травня 2020 р. під час науково-практичного онлайнсемінару «Дистанційні психологічні дослідження в умовах пандемії COVID-19 і карантину», організованого Інститутом соціальної та політичної психології НАПН України, Інститутом психології імені Г.С. Костюка НАПН України та факультетом психології Київського національного університету імені Тараса Шевченка). Проведені дослідження засвідчують, що стан суспільної свідомості нині в Україні є загалом задовільним, проте характеризується низкою суперечностей і не завжди збігається з тими уявленнями про нього, які домінують у засобах масової інформації та соціальних мережах.

1. Інтенсивність стресової реакції на ризик захворіти або необхідність дотримуватися обмежувальних і захисних заходів серед громадян України виявилася досить помірною. 
Хоча ЗМІ нерідко розповідають про поширеність панічних реакцій, дослідження не фіксують різкого стрибка психоемоційних розладів та/або психічних дисфункцій у відповідь на пандемію. Певний виняток становлять лише окремі категорії громадян, наприклад, батьки з малими дітьми та дітьми шкільного віку, інтенсивність стресу в яких $\epsilon$ помітно вищою за спонтанно встановлену загальносуспільну «норму» реакції.

2. Попри загалом задовільний стан суспільної свідомості спостерігається виразна поляризація суспільних реакцій на пандемію. Частина населення дуже серйозно поставилася до епідеміологічної загрози, відчуваючи інтенсивну тривогу за власне здоров'я та здоров'я близьких. Інша частина, навпаки, категорично заперечує та ігнорує небезпеку, іноді свідомо наражаючи себе та інших на ризик захворіти. Тому очевидно, що й сама поляризація, і обидві крайні форми реагування на епідемію коронавірусу в перспективі можуть створити певні труднощі під час поновлення економічної, соціальної та політичної активності населення.

3. у ЗМІ за сприяння деяких недостатньо компетентних або малообізнаних експертів надмірно мусуються уявлення про те, що з огляду на різку зміну умов і ритмів соціального життя основні психологічні труднощі в громадян виникають у площині контактів із найближчим оточенням (родина, друзі, сусіди). Через це значна кількість рекомендацій щодо підтримання соціальнопсихологічного благополуччя населення, вочевидь, не влучає в ціль, адже насправді основним джерелом психологічного напруження $€$ макросоціальні чинники, серед яких найбільше значення мають відносини громадян із владою. Попередні дані досліджень фіксують, що ставлення до інститутів центральної влади (Президент, уряд, парламент) відчутно погіршується. Натомість люди зміцнюють горизонтальні зв'язки та кола довіри, і чи не єдиними представниками умовної «влади», що заслуговують на довіру, наразі $€$ медичні та педагогічні працівники.

4. У суспільстві поступово, але неухильно зростає відчуття несправедливого та нерівномірного розподілу пов'язаних із карантином труднощів між привілейованими представниками влади та великого бізнесу, з одного боку, і рештою громадян, з другого. Наразі карантинні обмеження починають сприйматись як такі, що «одним усе дозволено, іншим усе заборонено», а звичайні люди змушені брати на себе основний тягар соціальних, економічних і психологічних втрат, зумовлених карантином, не маючи жодної підтримки держави.
5. Джерело стресогенності ситуації дедалі помітніше зміщується з ії причин на наслідки. Уже зараз для українців основним джерелом стресу $є$ не хвороба як така, а суцільна невизначеність і невпевненість у власному економічному майбутньому.

6. Хоча більшість громадян загалом лояльно поставилися до запровадження обмежувальних і захисних заходів, але з розгортанням ситуації з'являється дедалі більше ознак їх саботажу та відміни, так би мовити, явочним порядком.

7. На стан суспільної свідомості негативний вплив справляють суперечності між центральною і місцевою владою, які загострюються із кожним продовженням карантину і можуть набути ще більшої гостроти після запровадження його адаптивної фази. Це може, у свою чергу, посилити відцентрові тенденції та істотно вплинути на результати місцевих виборів (у конфлікті між центром і регіонами виборці можуть узяти сторону місцевої влади як більш близької, зрозумілої і «своєї», такої, що захистила їх від «надмірностей» карантинного режиму).

8. Психоемоційне напруження у суспільстві, зумовлене хоч і помірним, але тривалим стресом, має тенденцію до накопичення і відтак здатне спричинити розгортання відтермінованих дезадаптивних реакцій на пандемію і потягти за собою комплекс небажаних медичних, соціальних та економічних ризиків.

Перелічені суперечності, якими характеризується нинішній стан суспільної свідомості, посилюються під впливом низки провокативних чинників, серед яких:

- непослідовність і суперечливість комунікацій щодо запровадження та скасування обмежувальних заходів. Наприклад, було задекларовано встановлення блок-постів на кордонах областей, але цього здебільшого не зроблено. Також різні джерела повідомляють про неоднаковий рекомендований розмір дистанції між людьми в публічних місцях - один, півтора чи два метри. Або, навпаки, незважаючи на постійні зміни пов'язаної з пандемією ситуації, проголошуються одні й ті самі повідомлення (прикладом може слугувати звернення до населення Державної служби України з питань надзвичайних ситуацій, яке впродовж понад двох місяців транслює один і той самий текст);

- недостатня правова визначеність обмежувальних заходів, що надає представникам правоохоронних органів можливість довільно трактувати факти правопорушень або вибірково застосовувати санкції (за одне й те саме порушення можуть покарати або не покарати - залежно від обставин і суб'єктів скоєння правопорушення); 
- цілковите припинення легальних міжміських транспортних сполучень, попит на які задовольняють за надмірну плату «ліві» перевізники, котрі не дотримуються обмежень щодо кількості пасажирів, не забезпечують необхідних заходів безпеки i, дискредитуючи саму ідею карантинних заходів, сприяють де-факто поширенню епідеміологічної загрози;

- розсинхронування і неузгодженість рішень про часткове зняття карантинних обмежень, що викликало транспортний колапс у столиці та інших великих містах;

- неетична або невиважена поведінка представників органів державної влади. Ідеться, наприклад, про неналежне дотримання членами уряду та парламенту маскового режиму, порушення заборони на роботу деякими закладами громадського харчування, котрі афільовані 3 представниками влади, тощо. Варто згадати також необережну ремарку головного санітарного лікаря України В. Ляшка щодо закриття громадських парків винятково для вчинення психологічного впливу на населення;

- ухвалення рішень щодо послаблення карантинних заходів, так би мовити, навздогін, під тиском протестних акцій або слідом за самоскасуванням обмежень, до якого громадяни вдаються явочним порядком;

- поширення у деяких засобах масової інформації даних щодо перспектив ледь не тотального переходу підприємств, організацій та компаній як приватного, так і державного сектору на дистанційні форми роботи на постійній основі. Це є формою зловживання карантином і провокує загрозу саботажу частиною працівників повернення на докарантинний режим діяльності.

Усі ці чинники істотно збільшують ризик цілковитої дискредитації вжитих обмежувальних заходів, підривають потенціал належної національної відповіді на виклики пандемії і можуть серйозно ускладнити повторне запровадження карантину в разі нових спалахів захворюваності. Удруге люди можуть просто не повірити владі та відповісти на обмеження їх масовим ігноруванням. Найгіршим варіантом розвитку подій у недалекому майбутньому може стати намагання запровадити обмежувальні заходи, яких уже ніхто не дотримуватиметься. Тому потрібно зосередити зусилля на запобіганні такому варіанту, враховуючи ймовірність розгортання відтермінованих суспільних реакцій.

Ці реакції можуть розвиватися за кількома напрямами одночасно:

1. Сплеск депресивних, тривожних, фобічних, посттравматичних стресових та інших важких і надважких психічних розладів у відповідь на істотне погіршення соціально-економічної ситуації.

2. Саботаж і заперечення необхідності захисних та обмежувальних заходів.

3. Зростання соціального невдоволення і протестних настроїв.

3 огляду на нагальну потребу послаблення обмежувальних заходів для перезапуску економічної активності, а також на високу ймовірність виникнення нових епідеміологічних хвиль захворюваності на коронавірусну інфекцію, нині вбачаємо два найактуальніші завдання у сфері забезпечення гармонійних суспільних відносин і підтримання психоемоційного стану населення у межах норми.

Перше - домогтися масового дисциплінованого дотримання громадянами мінімуму необхідних заходів безпеки та дистанціювання в умовах фактичної відміни зовнішніх обмежувальних заходів, що знизить загрозу розвитку нових епідеміологічних спалахів.

Друге - нейтралізувати або істотно послабити тенденції до зростання протестних настроїв, соціального невдоволення і відцентрових тенденцій, що дасть змогу зберегти керованість ситуацією.

Для реалізації цих завдань вважаємо за доцільне запропонувати такі рекомендації:

1. Передбачити визначення (за допомогою фахових соціологічних і психологічних досліджень) категорій населення з різним типом ставлення до пандемії та карантинного режиму і налагодити цільову комунікацію із цими категоріями відповідно до визначеного типу ставлення, доступного обсягу економічних і соціальних ресурсів, типу поселення, інфраструктурних можливостей тощо.

2. Унормувати стислий перелік аргументованих і несуперечливих обмежувальних заходів (мінімально необхідний масковий режим, рукавички, дистанціювання тощо). Цей перелік має містити лише ті вимоги, можливість дотримання яких $\epsilon$ гарантованою та доведеною всіма громадянами без винятку. Із цього переліку мають бути вилучені заходи, які громадяни вже відмінили явочним порядком.

3. Належно забезпечити можливості та умови для неухильного виконання громадянами запроваджених обмежувальних заходів.

4. Підтримувати систематичне комунікаційне супроводження запроваджених обмежень для усіх верств суспільства. Люди мають «вивчити» правила перебування у громадських місцях як абетку. Також люди повинні чітко розуміти причини запровадження цих заходів та умови, за 
яких вони можуть бути змінені. Тут не має бути жодної двозначності або невизначеності. Заходи повинні бути універсальними, обов'язковими та всеохопними. Як канал комунікації доцільно використовувати регулярні «комунікативні» рейди патрульної поліції, що за допомогою гучного зв'язку постійно нагадуватимуть населенню про потребу дотримання обмежувальних заходів.

5. Домогтися невідворотності покарання за порушення обмежувальних заходів. Санкції за порушення мають бути помірно жорсткими, але невідворотними, всезагальними та зрозумілими. Можливість довільного трактування працівником поліції факту порушення і масштабу санкції має бути повністю усунена.

6. Підкріплювати бажану поведінку населення всіма можливими способами позитивної підтримки. За кожної сприятливої нагоди висловлювати громадянам вдячність за турботу про себе та інших людей, за сумлінну та свідому поведінку, зміцнювати у їхній свідомості почуття гідності та громадянської відповідальності.

7. Постійно задіювати як потужний інструмент впливу на суспільство особистий приклад політичних і громадських лідерів, інших «селебріті». Дотримання правил безпеки має стати не лише соціальною нормою, а й ознакою соціального престижу.

8. У роз'яснювальній роботі уникати «тригерних» для суспільної свідомості тем. Насамперед усього, що містить натяки на привілейованість одних громадян порівняно з іншими та несправедливість розподілу втрат, пов'язаних із пандемією. Кожен такий випадок має піддаватися недвозначному та миттєвому осуду інститутів влади.

9. Не заперечуючи скрутних обставин, у яких через зупинення економічної діяльності опинилося чимало родин, просувати водночас риторику надії та дієвої солідарності. Формувати позитивну ідентичність як підґрунтя колективної дії («ми, українці, вміємо гідно зустрічати випробування»). Апелювати до позитивних прикладів із національного та загальнолюдського минулого, проєктувати позитивні очікування на майбутнє.

10. Орієнтуючись на суспільні настрої, розглянути можливість показового покарання тих, хто найбільше «нажився (чи наживається) на карантині», зокрема «лівих» перевізників.

11. Оптимізувати взаємодію у системі «центр регіони», переконливо доносячи до громадськості як ії позитивні результати, так і причини та наслідки недосягнення згоди чи порозуміння.

Окрім того, слід розробити та чітко прокомунікувати різні сценарії трансформації карантину, включно з умовно негативним, що передбачає не послаблення, а навпаки, посилення обмежувальних заходів. Варто також передбачити регулярне консультування у МОЗ України різних категорій фахівців, які працюють 3 населенням (журналістів, правоохоронців, освітян, представників експертного середовища тощо), щодо просування та аргументації єдиних правил поведінки за того чи того сценарію.

\section{СПИСОК ВИКОРИСТАНИХ ДЖЕРЕЛ}

Слюсаревський, М. (2018). Маса як об'єкт соціальнопсихологічного пізнання: розпорошений стан і феномен сконцентрованості. Проблеми політичної психологіï, (7), 3-29. https://doi.org/10.33120/popp.v21i1.42

Слюсаревський, М.М. (2020, травень-червень). Стан суспільної свідомості та заходи з його поліпшення в умовах пандемії Covid-19. Педагогічна газета, (3), 4.

Слюсаревський, М.М., Найдьонова, Л.А., \& Вознесенська, О.Л. (ред.). (2020). Досвід переживання пандемії COVID-19: дистанційні психологічні дослідження, дистанційна психологічна підтримка : матеріали онлайн-семінарів 23 квітня 2020 року. «Досвід карантину: дистанційна психологічна допомога і підтримка» та 15 травня 2020 року. «Дистанційні психологічні дослідження в умовах пандеміï Covid-19 і карантину». https:// bit.ly/36gvhGW

\section{THE STATE OF PUBLIC CONSCIOUSNESS AND STEPS TO IMPROVE IT IN THE COVID-19 PANDEMIC CONTEXT Scientific and analytical report}

Mykola Slyusarevskyy

PhD in Psychology, Corresponding Member of NAES of Ukraine, Director, Institute for Social and Political Psychology of the National Academy of Educational Sciences of Ukraine, Kyiv, Ukraine

Abstract. The previous results of public consciousness studies in the pandemic COVID-19 condition in Ukraine are analyzed. The leading trends and contradictions of the public response to pandemic threats are highlighted. In particular, it is shown that the intensity of the stress response to the risk of falling ill among the citizens of Ukraine was quite moderate. The main source of stress is not the disease, but continuous uncertainty and uncertainty in their own economic future. Provocative factors that may exacerbate the contradictions in the public mind and increase the likelihood of sabotage new quarantine restrictive are considered. The actual tasks in the field of ensuring harmonious social relations and maintaining the psycho-emotional state of the population within the norm are highlighted. The first is to achieve mass disciplined observance of the minimum of necessary security measures and distancing, which will reduce the threat of the development of new epidemiological outbreaks. The second is to neutralize or significantly weaken the tendencies to increase protest moods, social discontent and centrifugal tendencies, which will allow to maintain control over the situation.

Keywords: pandemic; public consciousness; risks; restrictive measures; stress.

Дата публікації: 5 листопада 2020 р. 